\title{
OPEN Full scale tests of various buried flexible structures under failure load
}

\section{Adam Wysokowski}

The aim of the tests described in the paper was conducting a displacement and stress analysis of four buried flexible structures made in different technologies under failure load. Generally, the laboratory tests carried out on in full scale confirms that all four culvert models of the work safely despite the reduction of the backfill layer over the structures to $0.3 \mathrm{~m}$ (less than according to standard recommendations) and increasing the load to $1960-2000 \mathrm{kN}$ (almost 4 times more than according to standards and recommendations). In the case of a PE plastic pipe, the main measured parameter was displacement and for other steel research models it was the stress. The obtained maximum values of these parameters were compared with the permissible standard values. Maximum displacement values were recorded in the crowns of the structures up to $12.57 \mathrm{~mm}$ for PE plastic pipe model. The maximum stresses for steel structures were $85.28 \mathrm{MPa}$ (for corrugated steel pipe), 111.5 MPa (Box Culvert) and 447.9 MPa (Multi Plate non-circular structure). Despite the exceed stress in the case of Multi Plate structure, the steel structure did not lose its stability. The analyses carried out were aimed at determining database, which in its assumption, allows the verification of calculations performed by a numerical method such as FEM.

The article attempts to evaluate the comparison values of the culvert displacements and stresses made in four different technologies with the permissible standard values based on laboratory tests on a natural scale. Models were made using PE plastic and corrugated steel sheets. In this case, the results of the structural tests were compared under a failure load.

An example of damage caused by an overload of buried flexible structure is shown in Fig. 1.

The topic described in the paper is very important due to the fact that in recent years, research and analysis of culverts under various types of loads are still being carried out. This is related to both culverts in situ tests ${ }^{1-4}$, as well as numerical analysis of different load cases ${ }^{5-9}$.

In the case of buried flexible structures, the impact of the backfill on the soil-shell interaction is less pronounced than in the case of rigid structures. This is because in these structures, once the ground is made, a natural vault is formed in the backfill, limited from the top by the road surface and from the bottom by the curvature of the structure. This phenomenon is called "vaulting", although in the natural situation it occurs as a result of creating a hole inside the stabilized natural soil and not in the embankment of the soil-covered structure under construction $^{10}$. In such a situation, the dead load of the layers (soil backfill and roadway substructure) and the live loads cause much less reaction on the foundation than in a rigid (classic) vaulted structure. In the case of buried flexible structures, the interaction of the flexible structure with the soil backfill is employed. Therefore the main load-bearing structure is the soil backfill as well as the reinforcing geotextiles. In the case of rigid culverts, the backfill is only the filling without significant interaction.

Despite the extensive theoretical research that has been carried out to model soil-structure interactions leading to many mathematical relationships and empirical equations, most of them present a shortcoming in considering the actual soil-shell-interaction response. One common way to obtain real information about this interaction is to develop a physical model capable of providing various conditions ${ }^{11,12}$. Such model allows the measurement of most parameters related to the behavior of the buried flexible structure with high accuracy. At the same time, the model allows, to measuring parameters under various service loads (static, dynamic and fatigue), and also to determine the mechanism of failure of such structures under an extreme live load. It is the most accurate method of performing such analyzes ${ }^{13}$, which can certainly be supplemented with the most modern FEM analyzes, including heterogeneous models of structure material ${ }^{14}$.

Road, Bridge and Railway Department, Faculty of Civil Engineering, Architecture and Environmental Engineering, University of Zielona Góra, Prof. Z Szafrana St. No. 1, Building A-8, 65-417 Zielona Gora, Poland. email: awysokowski@infra-kom.eu 


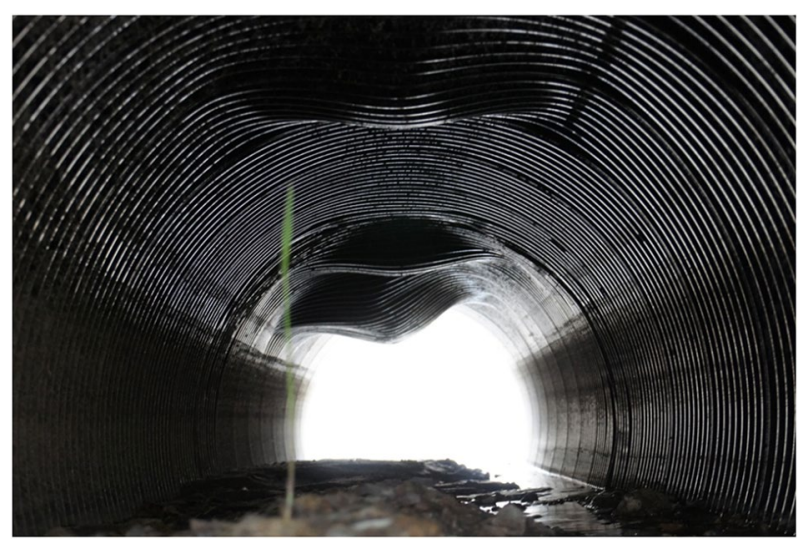

Figure 1. An example of damage caused by overloading a road buried flexible steel structure. Visible deformations in the places of the vehicle axis run-up.

\begin{tabular}{|l|l|l|}
\hline Parameter & Unit & Value \\
\hline Sand indicator & $\%$ & 92.5 \\
\hline Optimal moisture content & $\%$ & 9.5 \\
\hline Compaction by proctor & $\mathrm{g} / \mathrm{cm}^{3}$ & 1.990 \\
\hline Bulk density & $\mathrm{g} / \mathrm{cm}^{3}$ & 1.74 \\
\hline Bearing capacity CBR $(5,0)$ & $\%$ & 17.0 \\
\hline Aggregate abrasion by the Los Angeles method & $\%$ & 26.0 \\
\hline
\end{tabular}

Table 1. Properies of soil backfill.

The article presents the results of analyzes of four full-size laboratory cases made in different technologies. In all cases, the applied loads exceeded the assumed standard loads by $400 \%$. The studies provide a good basis for assessing the accuracy and reliability of the commonly used finite element analysis methods ${ }^{15,16}$.

It should be noted that compared to numerical analysis, building, testing, and then the demolition of the natural scale model requires a very large financial outlays. For this reason, such studies are conducted less frequently in the world.

\section{Materials and methods}

Four research models made in different material technology were tested on a natural scale. The main purpose of the research was to compare the displacement and stress values of structures under failure load. Tests were carried out on the station for static, dynamic and fatigue tests, which consists of a reinforced concrete foundation with a length of $80.0 \mathrm{~m}$ and a width of $20.0 \mathrm{~m}$ together with a hall and a steel frame constituting a retaining construction for hydraulic load-inducing devices.

Research models were constructed in all technological steps of the buried structure based on the applicable transport engineering standards and regulations, included additionally geometric control of the test models, mounting sensors and gauges on the structures and soil backfilling with mechanical compaction with $30.0 \mathrm{~cm}$ thick layers. Displacement and stress measurements were carried out using sensors and induction gauges in characteristic points of the structures. The applied loads were in accordance with the Polish transport engineering standards. The load variant replacing the railway load was used in the laboratory tests. Failure tests of culvert models were carried out for several different values of load forced by hydraulic actuators and for different values of backfill layer over the structures. The article describes the results for maximum loads and backfill layer equal $0.3 \mathrm{~m}$. The backfilling material was well-graded soil with a maximum grain size of $32 \mathrm{~mm}$. The basic parameters of soil backfill are summarized in Table 1 .

The aim of laboratory tests on a natural scale was to create a knowledge base on the behavior of buried structures under various types of loads. This database, in its assumption, allows the verification of calculations performed by a numerical method such as FEM.

Description of PE plastic and steel corrugated models. The research covered two culverts with a diameter of $0.80 \mathrm{~m}$ and a length of $13.70 \mathrm{~m}$. The first research model was made of a PE plastic pipe. The second model was a flexible corrugated steel pipe. The soil conditions for both models were similar due to constant monitoring of the degree of compaction of soil backfill layers and of the lateral zone of the structures. Figure 2 shows a cross-section of the research models.

Figure 3 present general view of test model for research. 


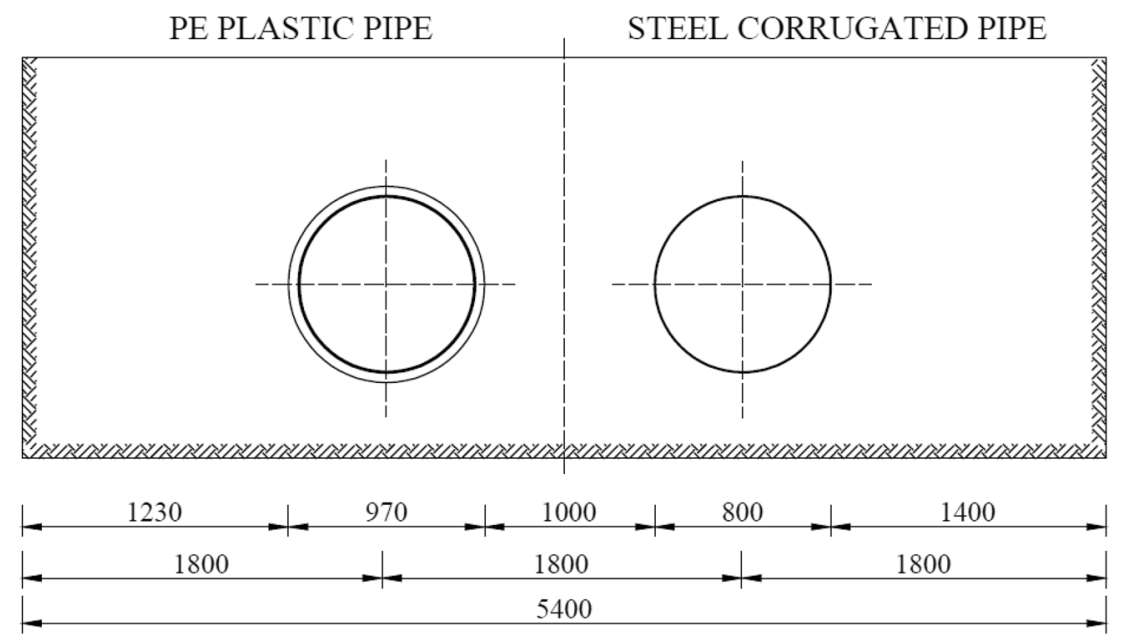

Figure 2. Cross-section of the research models: PE plastic pipe and steel corrugated pipe.

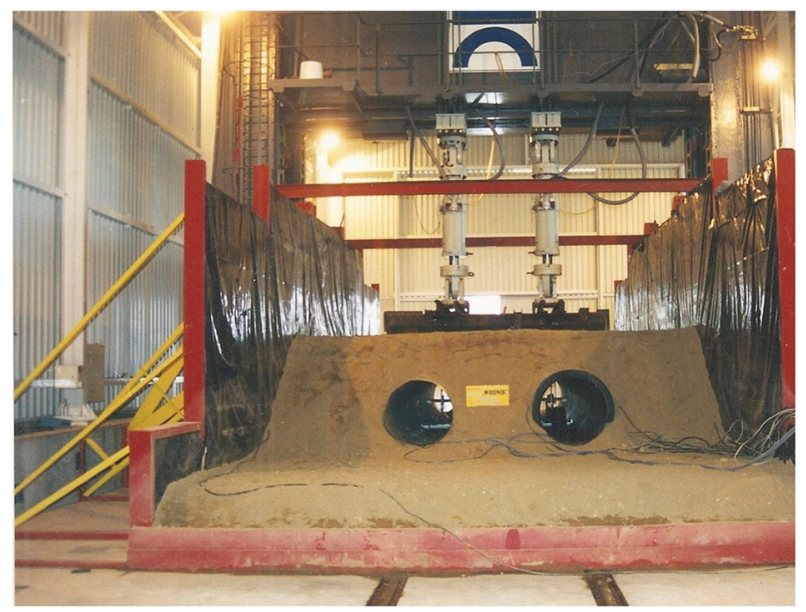

Figure 3. General view of the research models after soil backfill.

\begin{tabular}{|l|l|l|}
\hline Parameter & Unit & Value \\
\hline Nominal diameter & $(\mathrm{mm})$ & 800.0 \\
\hline Outside diameter & $(\mathrm{mm})$ & $970 \pm 2 \%$ \\
\hline Inside diameter & $(\mathrm{mm})$ & $800 \pm 2 \%$ \\
\hline Area & $\left(\mathrm{m}^{2}\right)$ & 0.50 \\
\hline Period of corrugation & $(\mathrm{mm})$ & 140.0 \\
\hline Ring stiffness & $\mathrm{kPa}$ & 6.0 \\
\hline Density & $\left(\mathrm{g} / \mathrm{cm}^{3}\right)$ & 0.942 \\
\hline
\end{tabular}

Table 2. Parameters of the pipe made of PE plastic.

The basic parameters of PE plastic pipe are summarized in Table 2. Table 3 contains the list of the basic parameters of pipe made of corrugated steel sheets.

The laboratory failure tests were carried out for the following maximum loads:

- maximum pressure force: $\mathrm{F}_{\max }=1960 \mathrm{kN}$.

- maximum force per actuator: $\mathrm{F}_{\max } / 2=980 \mathrm{kN}$.

Failure tests of research models were carried out according to the diagram shown in Fig. 4. 


\begin{tabular}{|l|l|c|}
\hline Parameter & Unit & Value \\
\hline Nominal diameter & $(\mathrm{mm})$ & 800.0 \\
\hline Sheet thickness & $(\mathrm{mm})$ & 2.0 \\
\hline Area & $\left(\mathrm{m}^{2}\right)$ & 0.50 \\
\hline Weight & $(\mathrm{kg} / \mathrm{m})$ & 47.8 \\
\hline Tensile strength & $(\mathrm{MPa})$ & 270.0 \\
\hline Yield point & $\mathrm{MPa}$ & 250.0 \\
\hline
\end{tabular}

Table 3. Parameters of the pipe made of corrugated steel sheets.

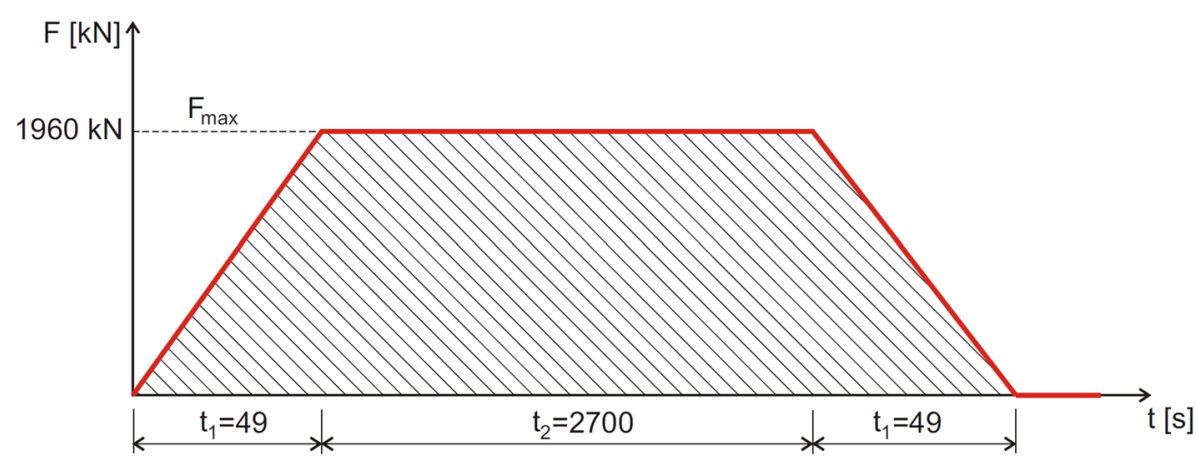

Figure 4. Diagram of the failure load.

PE PLASTIC PIPE

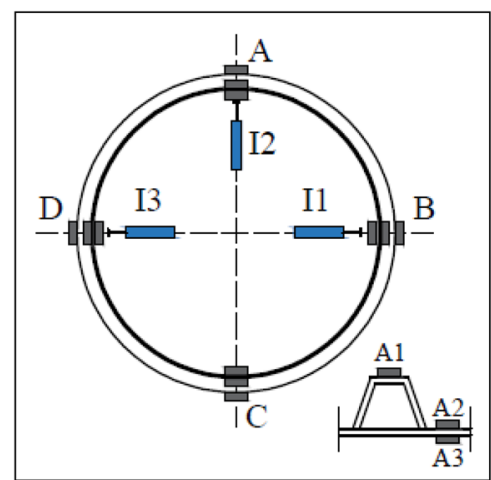

STEEL PIPE

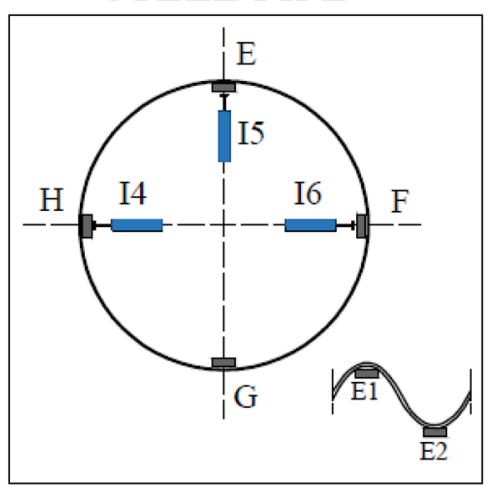

I1 - I6 - Inductive sensors

A - H - Electric resistance strain gauges

Figure 5. Arrangement of induction sensors and strain gauges for the testing models.

Displacement measurements were carried out using induction gauges located in the vertical axis (in the crown) and in the horizontal axis (on both opposite side walls). Stress measurements were carried out using electric resistance strain gauges located in the vertical axis and in the horizontal axis (on both opposite side walls). The arrangement of the induction sensors and strain gauges is shown in Fig. 5.

Box Culvert test model. The next stage of research concerned Box Culvert model under failure load. The research covered a culvert with a span of $3.55 \mathrm{~m}$ and a height of $1.42 \mathrm{~m}$. The steel structure was additionally reinforced by special ribs made of steel plates located on the top section of perimeter-in the crown. Figure 6 shows a cross-section of the research model.

A general view of the steel structure for testing is shown in Fig. 7. Figure 8 presents a general view of the research model after soil backfill.

Type of the model profile is a box with open cross-section. Other basic parameters of the tested structure are summarized in Table 4.

The laboratory failure tests were carried out for the following maximum loads: 


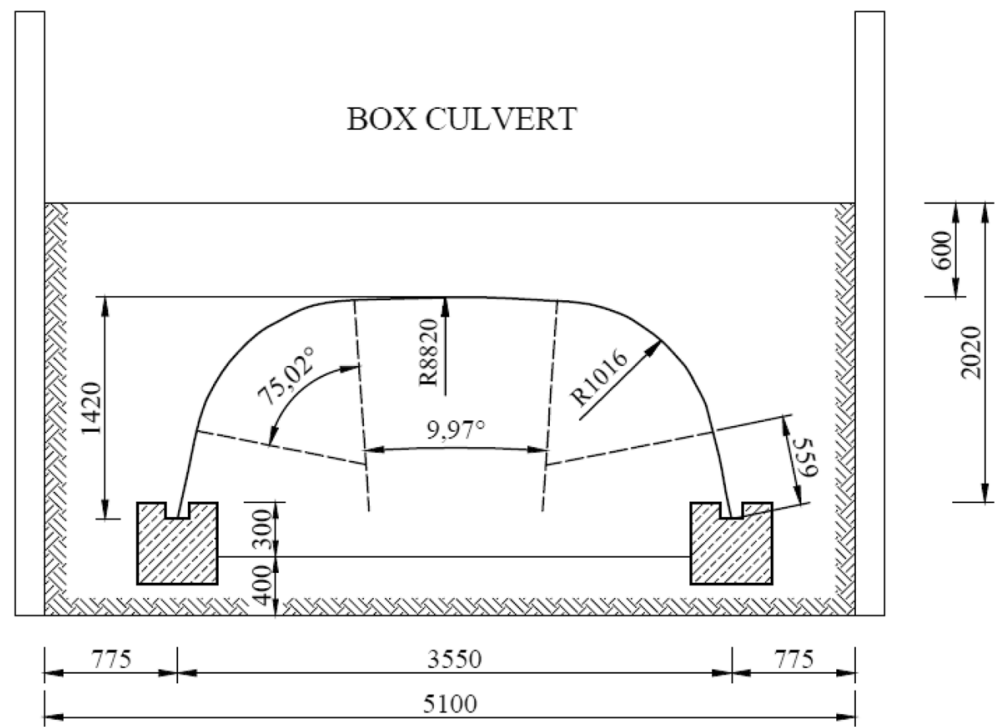

Figure 6. Cross-section of the research model: Box Culvert.

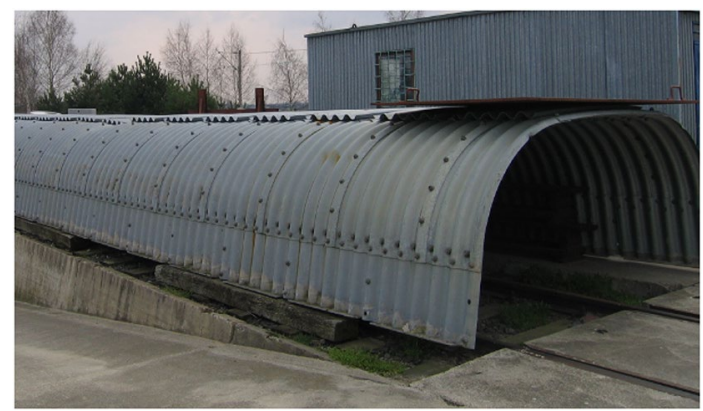

Figure 7. General view of the tested steel box structure.

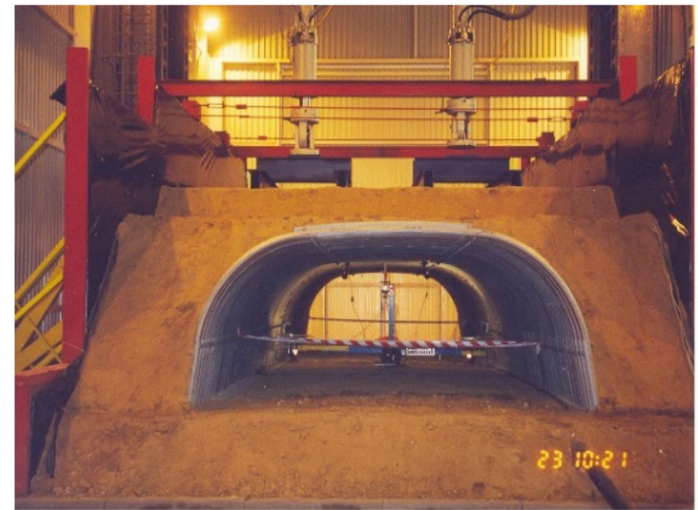

Figure 8. General view of the research model after soil backfill.

- maximum pressure force: $\mathrm{F}_{\max }=1990 \mathrm{kN}$,

- maximum force per actuator: $\mathrm{F}_{\max } / 2=995 \mathrm{kN}$.

The speed of the load was $40 \mathrm{kN} / \mathrm{s}$ with the time of the maximum load $\mathrm{T}=600 \mathrm{~s}$. 


\begin{tabular}{|l|l|l|}
\hline Parameter & Unit & Value \\
\hline Thickness of the steel plate & $(\mathrm{mm})$ & 5.0 \\
\hline Corrugation of the steel plate & $(\mathrm{mm})$ & $150.0 \times 50.0$ \\
\hline Length & $(\mathrm{m})$ & 13.7 \\
\hline Tensile strength & $(\mathrm{MPa})$ & 270.0 \\
\hline Yield point & $(\mathrm{MPa})$ & 250.0 \\
\hline Cross-section of concrete foundations & $(\mathrm{m})$ & $0.50 \times 0.50$ \\
\hline
\end{tabular}

Table 4. Parameters of the Box Culvert research model.

\section{BOX CULVERT}

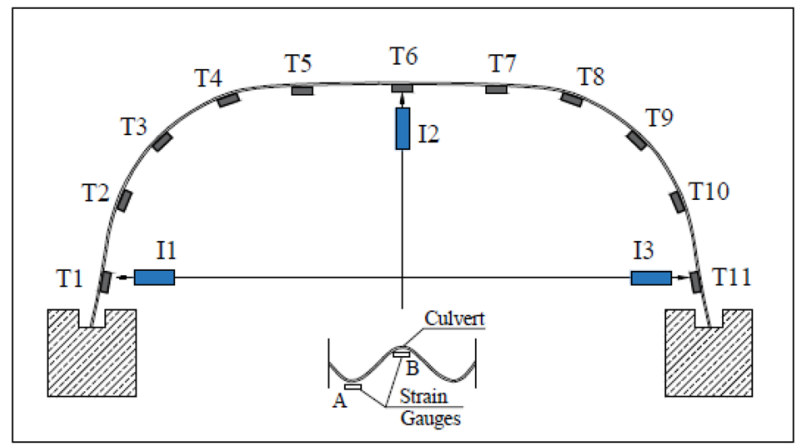

Description: $\quad$ I1 - I3 - Inductive sensors

$\mathrm{T} 1$ - T11 - Electric resistance strain gauges

Figure 9. Arrangement of induction sensors and strain gauges for the Box Culvert model ${ }^{1}$.

\begin{tabular}{|l|l|l|}
\hline Parameter & Unit & Value \\
\hline Thickness of the steel plate & $(\mathrm{mm})$ & 3.75 \\
\hline Width of the steel plate & $(\mathrm{mm})$ & 990.0 \\
\hline Corrugation of the steel plate & $(\mathrm{mm})$ & $150.0 \times 50.0$ \\
\hline Length & $(\mathrm{m})$ & 14.4 \\
\hline Tensile strength & $(\mathrm{MPa})$ & 270.0 \\
\hline Yield point & $(\mathrm{MPa})$ & 250.0 \\
\hline
\end{tabular}

Table 5. Parameters of the multi plate research model.

The data collecting equipment consisted of 22 electric resistance strain gauges in 11 locations, with a strain gauge on the top and bottom of the corrugation and 3 inductive sensors used for vertical and horizontal displacement measurements.

Figure 9 presents a schematic layout of strain gauges and induction sensors around the corrugated Box Culvert model ${ }^{1}$.

Description of the multi plate model. Another research model in natural scale was Multi Plate structure made of corrugated steel sheets. The research covered a culvert with a span of $2.99 \mathrm{~m}$ and a height of $2.40 \mathrm{~m}$. Other parameters of the research model are shown in Table 5. Figure 10 shows a cross-section of the Multi Plate model.

General view of the steel Multi Plate structure for testing is shown in Fig. 11. Figure 12 presents a general view of the research model ready for testing.

Described laboratory failure tests were carried out for the backfill layer over the structure equal $0.3 \mathrm{~m}$ and for the following maximum loads:

- maximum pressure force: $\mathrm{F}_{\max }=2000 \mathrm{kN}$,

- maximum force per actuator: $\mathrm{F}_{\max } / 2=1000 \mathrm{kN}$. 


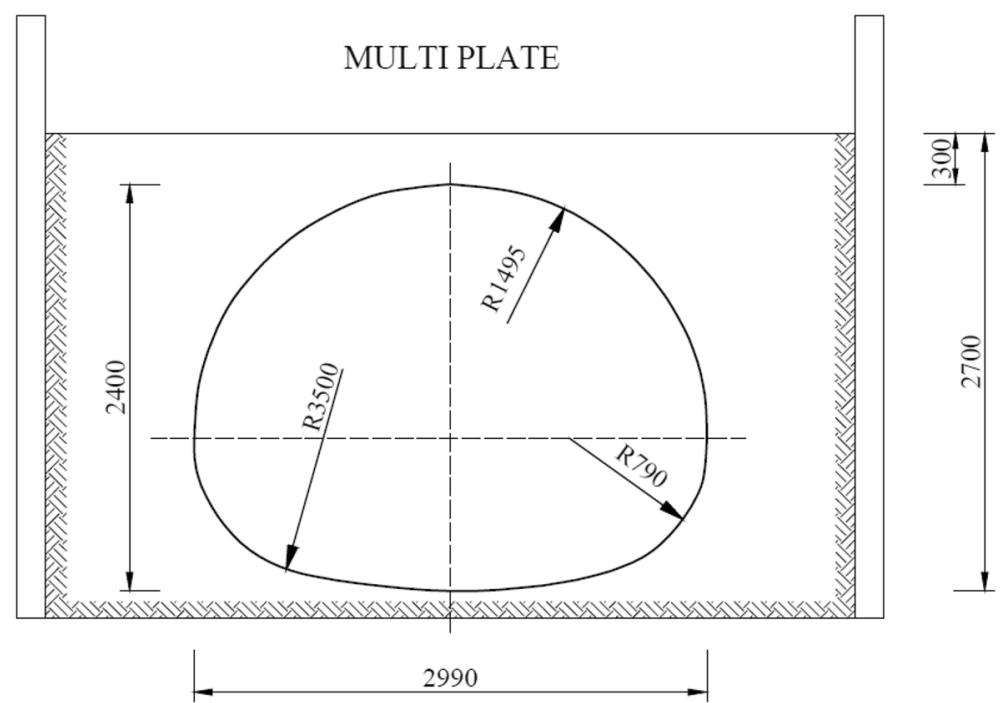

Figure 10. Cross-section of the research model: multi plate.

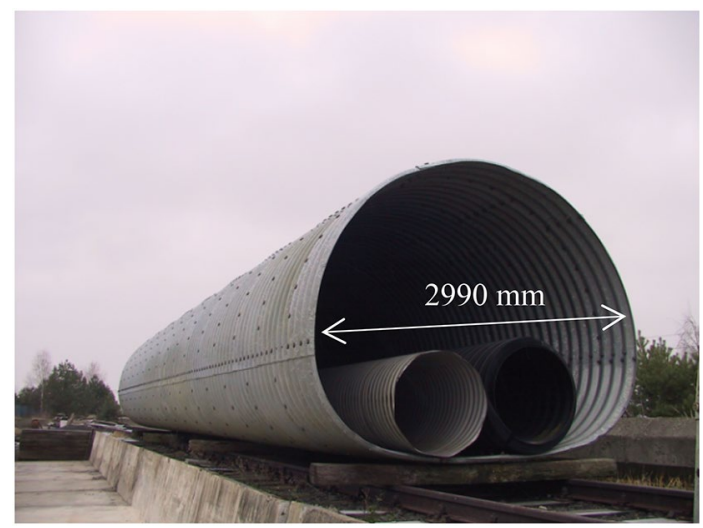

Figure 11. General view of the tested steel Multi Plate structure including the two pipes from the chapter 2.1.

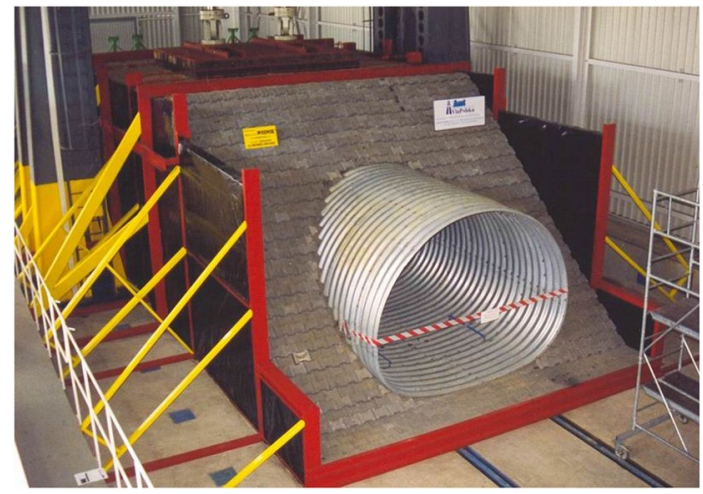

Figure 12. General view of the complete research model.

Displacement measurements were carried out using three inductive sensors located in the vertical axis (in the crown) and in the horizontal axis (on both opposite side walls). Stress measurements were carried out using 28 electric resistance strain gauges in 14 locations, with a strain gauge on the top and bottom of the corrugation. The strain gauges were located on the perimeter of the research model at equal distances of $631 \mathrm{~mm}$. The arrangement of the induction sensors and strain gauges is shown in Fig. 13. 
MULTI PLATE

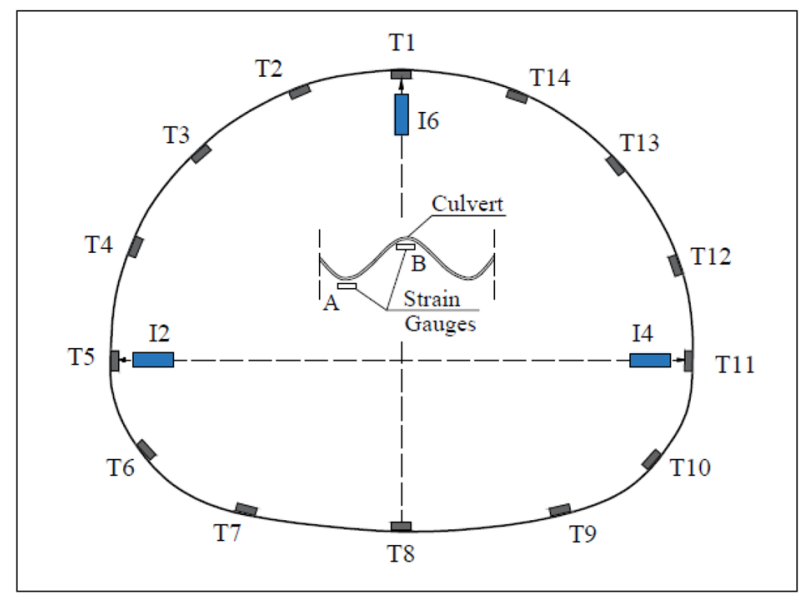

Description: I2, I4, I6 - Inductive sensors

T1 - T14 - Electric resistance strain gauges

Figure 13. Arrangement of induction sensors and strain gauges for the multi plate model.

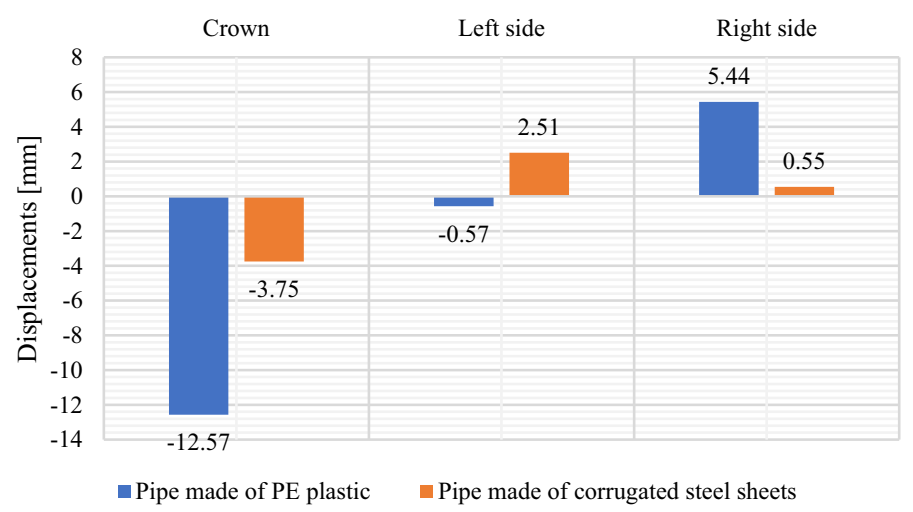

Figure 14. Maximum displacement values of the research models: PE plastic pipe and corrugated steel pipe.

Design standards. According to the Polish Standards in the case of buried structures made of PE plastic, an important parameter is the allowable deflection, which is equal to $3 \%$. When designing this type of structure, it is necessary to estimate the value of the maximum deflection during use of the object and compare it with the permissible value. Deflection of the structure results from the displacement and the span ratio ${ }^{17}$.

During the implementation of culverts made of corrugated steel sheets, compliance with the permissible values of wall stresses must be checked. The allowable stress value in this case is equal to the tensile strength of the steel from which the buried structure was made.

Ethical approval. This article does not contain any studies with human participants or animals performed by any of the authors.

\section{Results and analysis}

Test results. The results of displacements and stress measurements concern characteristic points of the structures. Test results were graphically developed for all research models under failure load. Maximum measured values in individual sensors are shown in Fig. 14.

Figure 8 shows displacement diagram recorded for structures made of PE plastic pipe and corrugated steel pipe. Presented displacements results pertain to inductive sensors located in the crown of the structures and in the horizontal axis on both opposite side walls (Fig. 5) marked as I1, I2 and I3 for PE plastic pipe and as I4, I5 and $\mathrm{I} 6$ for pipe made of corrugated steel sheets.

Figure 15 shows stress diagrams recorded for the strain gauges located in the horizontal axis, crown and bottom of the structures (Fig. 4).

Figure 16 shows maximum displacement values recorded for the induction sensors (I1 - I3) located in the horizontal axis and crown of the Box Culvert model (Fig. 9). 


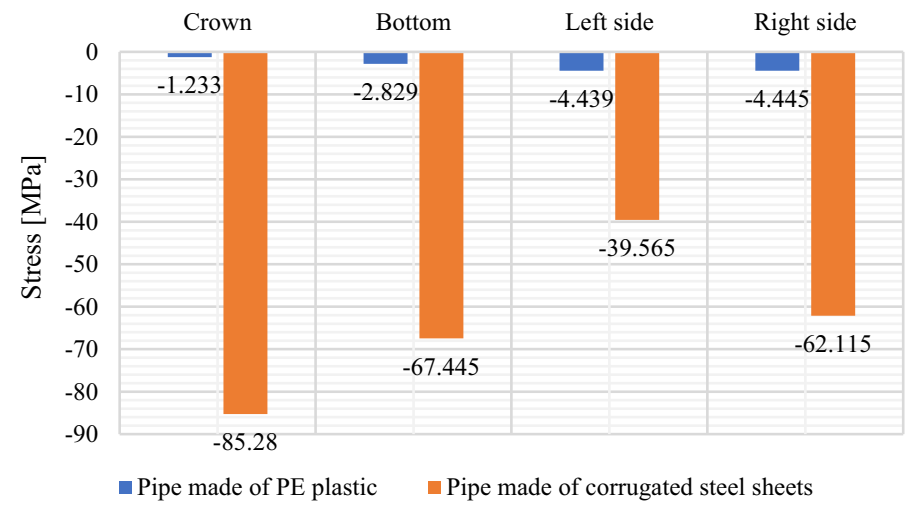

Figure 15. Maximum stress values in the research models: PE plastic pipe and corrugated steel pipe.

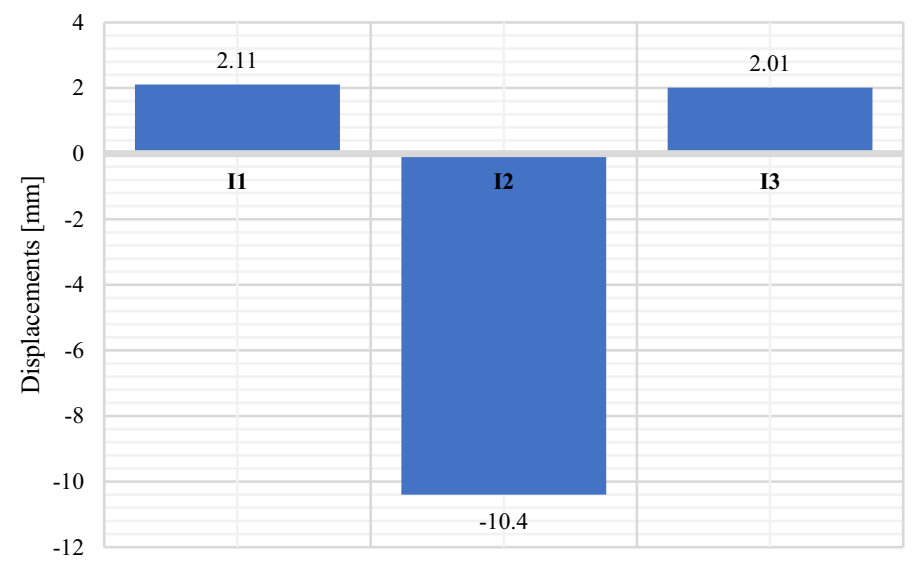

Figure 16. Maximum displacement values of the research model: Box Culvert.

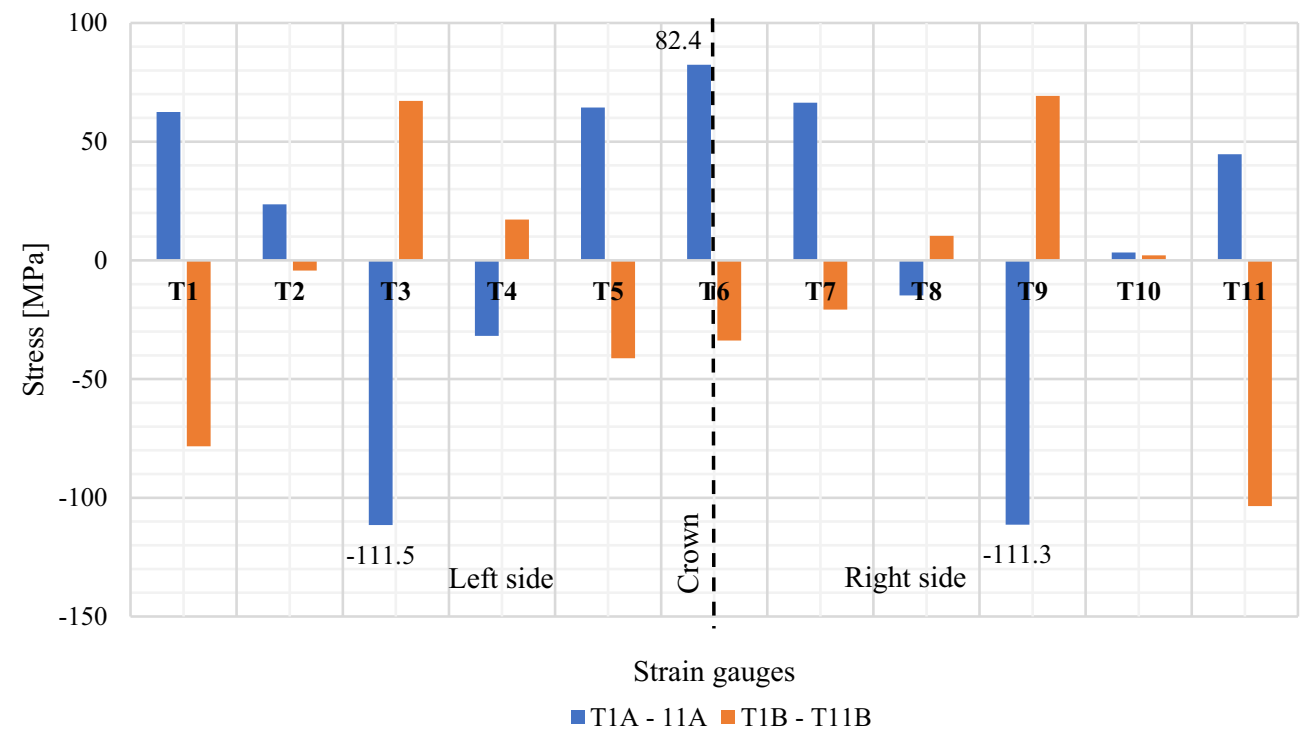

Figure 17. Maximum stress values in the research model: Box Culvert. 


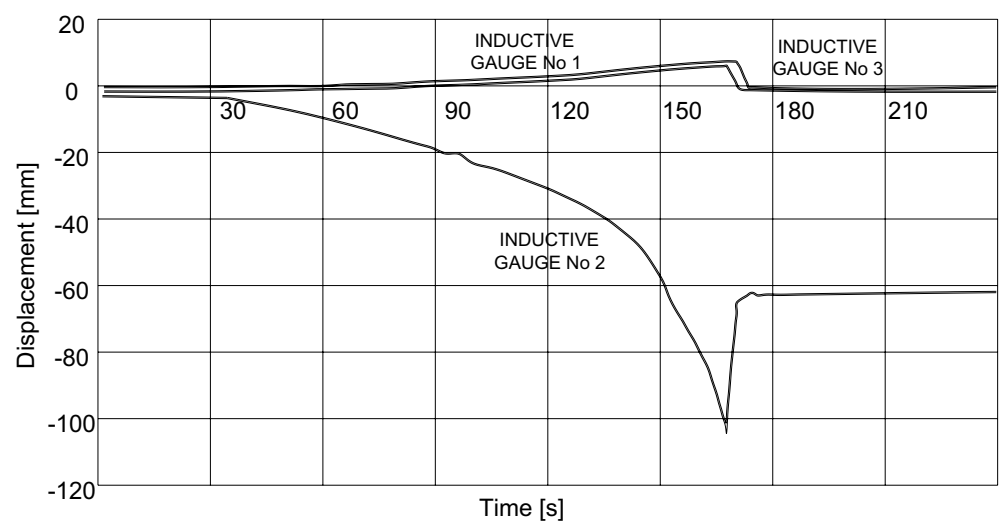

Figure 18. Example of vertical displacement under destructive load for Box Culvert structure.

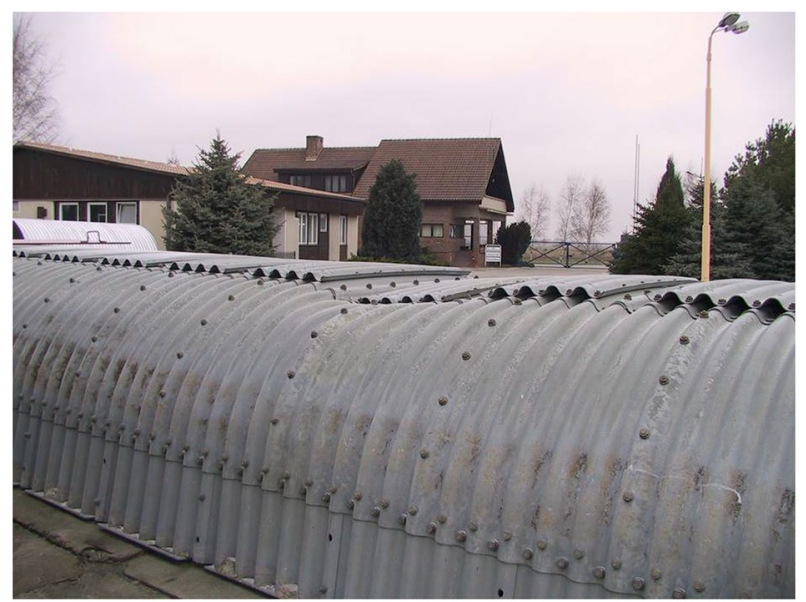

Figure 19. Local damage where the stiffness of the structure changes after the tests.

Figure 17 shows stress diagram recorded for Box Culvert model. Presented maximum stress results pertain to strain gauges marked as T1A-T11A and T1B-T11B (Fig. 6).

During the study also made an attempt to "destroy" the construction of box culvert. Due to the limited maximum vertical load (with a maximum load of $2000 \mathrm{kN}$ the structure showed no damage), the top layer of the soil backfill was removed for the destruction test, and the load was applied directly to the upper surface of the steel structure with only $10.0 \mathrm{~cm}$ soil cover.

In Fig. 18 are shown vertical displacements under destructive load for Box Culvert structure (for three inductive gauges).

Figures 19 and 20 show the effect of an attempt to destroy the box culvert structure by applying a load directly to the crown of steel structure (with only $10.0 \mathrm{~cm}$ soil contact layer).

Figure 21 presents displacements results pertain to inductive sensors located in the crown of the Multi Plate structure and in the horizontal axis on both opposite side walls marked as I2, I6 and I4 (Fig. 13).

Figure 22 shows stress diagram recorded for Multi Plate model. Presented maximum stress results pertain to strain gauges marked as T1A-T14A and T1B-T14B (Fig. 13).

Analysis of test results. The laboratory tests indicate the correct operation of all tested models. During the research, no factors were observed that would affect the need to change the test program and results. The obtained test results were subjected to appropriate analysis. For its ease, additional table was prepared with maximum results. Table 6 presents a summary of the maximum recorded values of the stress and displacements of the structures.

Table 7 compares the maximum displacement and stress values measured for the research culvert models with the permissible standard values.

Laboratory tests of culverts in natural scale under failure load with backfill layer over the structures equal $0.3 \mathrm{~m}$, did not show irregularities in the sense of stability and safety of work of the research models. As a result of the analysis of the displacement and stress values, the permissible standard values of these parameters were not exceeded, except for the stress value measured by the T12 sensor for the MultiPlate model (Fig. 13). Extreme 


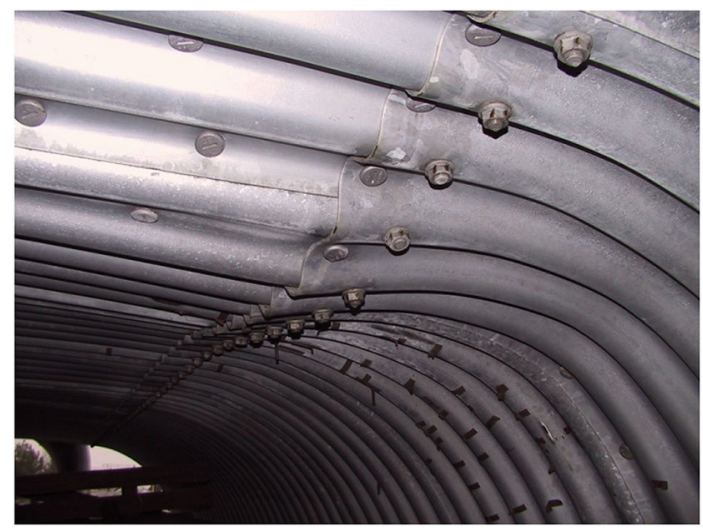

Figure 20. View of damage caused by concentrated load applied directly to the steel structure.

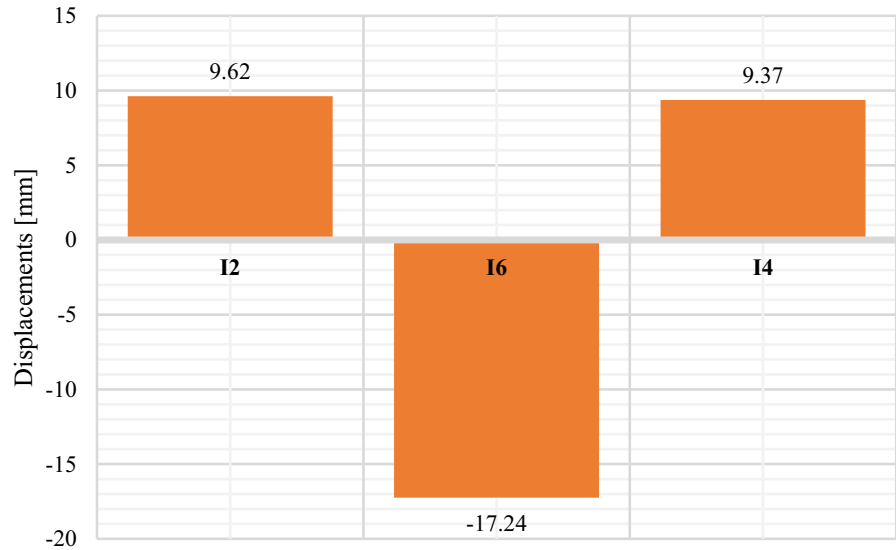

Figure 21. Maximum displacement values of the research model: multi plate.

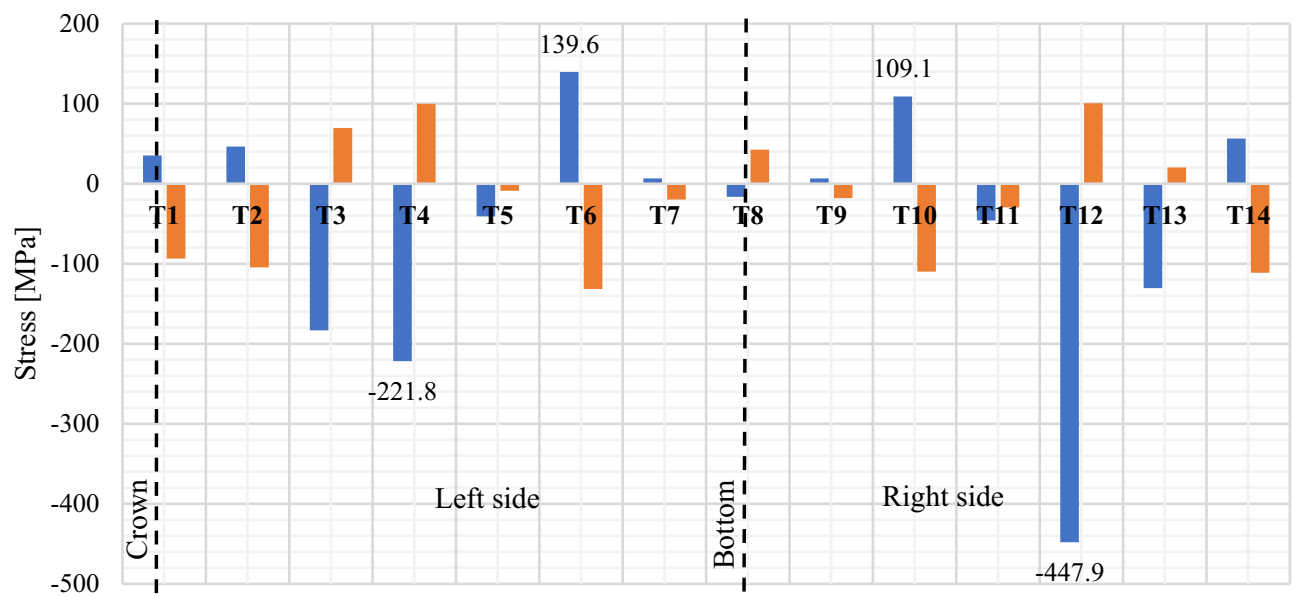

Strain gauges

$\because \mathrm{T} 1 \mathrm{~A}-14 \mathrm{~A}-\mathrm{T} 1 \mathrm{~B}-\mathrm{T} 14 \mathrm{~B}$

Figure 22. Maximum stress values in the research model: multi plate. 


\begin{tabular}{|c|c|c|c|c|c|c|c|c|}
\hline \multirow[b]{3}{*}{ Parameter } & \multicolumn{8}{|c|}{ Research model } \\
\hline & \multicolumn{2}{|c|}{ PE plastic pipe } & \multicolumn{2}{|c|}{$\begin{array}{l}\text { Corrugated steel } \\
\text { pipe }\end{array}$} & \multicolumn{2}{|c|}{ Box Culvert } & \multicolumn{2}{|c|}{ Multi plate } \\
\hline & Value & Sensor & Value & Sensor & Value & Sensor & Value & Sensor \\
\hline Displacement $(\mathrm{mm})$ & -12.57 & I2 & -3.75 & I5 & -10.4 & I2 & -17.24 & I6 \\
\hline Stress $(\mathrm{MPa})$ & -4.45 & B3 & -85.28 & E2 & -111.5 & T3 & -447.9 & T12 \\
\hline
\end{tabular}

Table 6. Maximum stress and displacement values of the tested models. Significant values are in bold.

\begin{tabular}{|l|l|l|l|}
\hline Research model & Parameter & Value & Permissible standard value \\
\hline PE plastic pipe & Deflection & $(12.57: 800.0) \times 100 \%=1.57 \%$ & $3 \%$ \\
\hline Corrugated steel pipe & Stress & $85.28 \mathrm{MPa}$ & $270 \mathrm{MPa}$ \\
\hline Box Culvert & Stress & $111.5 \mathrm{MPa}$ & $270 \mathrm{MPa}$ \\
\hline Multi Plate & Stress & $\mathbf{4 4 7 . 9} \mathrm{MPa}$ & $270 \mathrm{MPa}$ \\
\hline
\end{tabular}

Table 7. Comparison of maximum displacement and stress values with the permissible standard values. Significant values are in bold.

displacement and stress values occur at those measuring points where the maximum values for other load variants are recorded ${ }^{4,18}$. Similar course of internal forces is proof that the tested structures do not show a tendency to excessive deformation and do not change its rigidity during the load process.

Lowering the backfill layer below the minimum recommended value and increasing the load value imposed by the actuators did not cause complete destruction or deformation that would prevent the use of the structures.

\section{Conclusions}

In the article, an analysis of the behavior of buried structures made in different technologies under failure load was carried out. The conducted analysis showed that all tested structures behave in a safe manner. Almost symmetrical layout of measured stresses and displacements, it proves that the maximum load possible to obtain from actuators of 1960-2000 kN does not affect the change in stiffness and also the symmetry of the tested structures.

The results concerning the multiplate design were surprising. Despite exceeding the allowable stresses in the structure key (449.7 MPa), the thin-walled steel structure did not lose its stability. Probably the stability of structure results from the phenomenon of "soil interaction" with the thin-walled steel structure. This phenomenon is based on the redistribution of loads in the model under the influence of increasing load. Thus, the stresses in the soil on both sides of the shell increase through lateral deformation of the steel structure, which has an influence on the stresses / displacements in the crown of the structure. Additionally, no cracks were observed on the surface of the steel structure.

The comparison of the maximum displacement and stress values with the permissible standard values confirms the considerable load capacity of buried structures. In the case of accurate execution and compaction of backfill, the structures work correctly and safely even for a reduced backfill value over the structure to $0.3 \mathrm{~m}$ and at increased loads. The load value from 1960 to $2000 \mathrm{kN}$ significantly exceeds the maximum load resulting from Polish bridge design standards equal to $500 \mathrm{kN}$ (50 tons) and the maximum load according to NATO Standards (STANAG 2021 Military Load Classification of Bridges, Ferries, Rafts and Vehicles) equal to $600 \mathrm{kN}$ (60 tons).

A damage of flexible box structure was only possible under direct load placed on the steel structure with $10.0 \mathrm{~cm}$ soil cover (contact layer). It reflects that soil-structure interaction is a key for performance of these type of structures or pipes.

In the case of such hybrid structures, the susceptibility of the cover means that the backfill of the soil is clearly dominant as a structural substructure. An internal vault is created in the ground backfill which transfers the operational loads from the ground upwards away from the coating-what is referred as the "vaulting effect". This occurs mainly in the case of thin curved flexible structures-which naturally reflect the force flow in the soil. In the case of box-shaped objects, this phenomenon is limited, which is clearly visible in the analysis of the results. In addition, the vaulting effect occurs as the thickness of the upper layer increases.

In the initial phase, the flexible structure is merely only a formwork for creating the backfill geometry.

The behavior of soil-structure interface can be crucial to the overall response of a soil-structure system. The numerical simulation of soil-structure interaction problem requires proper modeling of the interface ${ }^{19}$.

Measurement data obtained during the laboratory tests in natural scale, in addition to the basis for scientific studies, give the possibility of more accurate calibration and verification of calculations performed by analytical and numerical method such as FEM. The analysis confirms that buried flexible steel structures are an alternative solution for traditional engineering facilities ${ }^{20}$. 
Received: 18 May 2021; Accepted: 22 December 2021

Published online: 25 January 2022

\section{References}

1. Regier, C., Hoult, N. A. \& Moore, I. D. Laboratory study on the behavior of a horizontal-ellipse culvert during service and ultimate load testing. J. Bridge Eng. https://doi.org/10.1061/(ASCE)BE.1943-5592.0001016 (2017).

2. Sheldon, T., Sezen, H. \& Moore, I. D. Joint response of existing pipe culverts under surface live loads. J. Perform. Construct. Fac. 29, 1 (2015).

3. Wang F., Jun Du Y., Zhou M., \& Zhang Y. J. Experimental study of the effects produced by a backfilling process on full-scale buried corrugated HDPE pipes in fine-grained soils. J. Pipeline Syst. Eng. Pract. (ASCE) (2015).

4. Yeau, K. Y., Sezen, H. \& Fox, P. J. Load performance of in situ corrugated steel highway culverts. J. Perform. Construct. Fac. https:// doi.org/10.1061/(ASCE)0887-3828(2009)23:1(32) (2009).

5. Alzabeebee, S. I. A., Chapman, D. N. \& Faramarzi, A. A comparative study of the response of buried pipes under static and moving loads. Transp. Geotech. 15, 39-46. https://doi.org/10.1016/j.trgeo.2018.03.001 (2018).

6. Goltabar, A. M. \& Shekarachi, M. Investigation of traffic load on the buried pipeline by using real scale experiment and plaxis-3D software. Res. J. Appl. Sci. Eng. Technol. 2(2), 107-113 (2010).

7. Muntakim A. H., Dhar A. S., \& Reza A. Modelling time dependent behavior of buried polyethylene pipes using Abaqus.in GeoEdmonton, the 71 st Canadian Geotechnical Conference (2018).

8. Wadi, A., Pettersson, L. \& Karoumi, R. FEM simulation of a full-scale loading-to-failure test of a corrugated steel culvert. Steel Compos. Struct. 27(2), 217-227. https://doi.org/10.12989/scs.2018.27.2.217 (2018).

9. Zhou, M., Wang, F., Du Jun, Y. \& Liu, M. D. Performance of buried HDPE pipes-part II: Total deflection of the pipe. Geosynth. Int. 24(4), 1-12. https://doi.org/10.1680/jgein.17.00010 (2017).

10. Machelski, C. Z. Effects of surrounding earth on shell during the construction of flexible bridge structures. Stud. Geotech. Mech. 41(2), 67-73. https://doi.org/10.2478/sgem-2019-0002 (2019).

11. Hosseini, S. M. M. \& Tafreshi, M. S. N. M. Soil-structure interaction of buried pipes under cyclic loading conditions. IJE Trans. $B$ Appl. 15(2), 117 (2002).

12. Machelski, C. Z. Estimation of internal forces in the shell of soil-steel structures on the basis of its displacements during backfilling. Stud. Geotech. Mech. 31(1), 1 (2009).

13. Sun, B. Adaptive multi-scale beam lattice method for competitive trans-scale crack growth simulation of heterogeneous concretelike materials. Int. J. Fract. 228, 85-101. https://doi.org/10.1007/s10704-021-00519-w (2021).

14. Sun, B. \& Xu, Z. An efficient numerical method for meso-scopic fatigue damage analysis of heterogeneous concrete. Construct. Build. Mater. 278, 122395. https://doi.org/10.1016/j.conbuildmat.2021.122395 (2021).

15. Beben, D. Soil-Steel Bridges. https://doi.org/10.1007/F978-3-030-34788-8 (Springer, 2020).

16. Wysokowski, A. Influence of Single-Layer Geotextile Reinforcement on Load Capacity of Buried Steel Box Structure Based on Laboratory Full-Scale Tests Thin-Walled Structures. 1-7. ISSN: 0263-8231, eISSN: 1879-3223. https://doi.org/10.1016/j.tws.2020.107312 (2020).

17. Wysokowski, A. \& Mońka, M. Laboratory full-scale comparative tests of rigid and flexible foundations of buried steel structures. Int. J. Steel Struct. 20, 808-816. https://doi.org/10.1007/s13296-020-00324-6 (2020).

18. Fleming, P. R., Faragher, E. \& Rogers, C. D. F. Laboratory and field testing of large diameter plastic pipe. Transp. Res. Rec. J. Transp. Res. Board 1594(1), 208-216. https://doi.org/10.3141/1594-24 (1997).

19. Liu, H., Song, E. \& Ling, H. I. Constitutive modeling of soil-structure interface through the concept of critical state soil mechanics. Mech. Res. Commun. 33(4), 515-531. https://doi.org/10.1016/j.mechrescom.2006.01.002 (2006).

20. Janusz, L. \& Madaj, A. Buried flexible steel engineering structures. Design and execution (Transport and Communication Publishers, Warsaw, 2009)

\section{Acknowledgements}

Research work was carried out at the Road and Bridge Research Institute as part of the implementation of ViaCon's buried steel flexible structures in Polish road and railway infrastructure. The author would like to thank both the grantor and the Road and Bridges Research Institute for the possibility of conducting this research.

\section{Author contributions}

I confirm that the article is written by me. This applies to figures, main text and substantive content.

\section{Funding}

Author declare that no funding has been received for the conduct of this study or preparation of this manuscript. Research work was carried out at the Road and Bridge Research Institute as part of the implementation of ViaCon's buried steel flexible structures in Polish road and railway infrastructure. The author would like to thank both the grantor and the Road and Bridges Research Institute for the possibility of conducting this research.

\section{Competing interests}

The author declares no competing interests.

\section{Additional information}

Correspondence and requests for materials should be addressed to A.W.

Reprints and permissions information is available at www.nature.com/reprints.

Publisher's note Springer Nature remains neutral with regard to jurisdictional claims in published maps and institutional affiliations. 
(c) (i) Open Access This article is licensed under a Creative Commons Attribution 4.0 International cc) License, which permits use, sharing, adaptation, distribution and reproduction in any medium or format, as long as you give appropriate credit to the original author(s) and the source, provide a link to the Creative Commons licence, and indicate if changes were made. The images or other third party material in this article are included in the article's Creative Commons licence, unless indicated otherwise in a credit line to the material. If material is not included in the article's Creative Commons licence and your intended use is not permitted by statutory regulation or exceeds the permitted use, you will need to obtain permission directly from the copyright holder. To view a copy of this licence, visit http://creativecommons.org/licenses/by/4.0/.

(C) The Author(s) 2022 